\title{
Chrysanthemum indicum microparticles on removal of hazardous Congo red dye using response surface methodology
}

\author{
J. Chukki ${ }^{1} \cdot$ S. Abinandan² $\cdot$ S. Shanthakumar ${ }^{1} \mathbb{D}$
}

Received: 19 June 2018 / Accepted: 8 November 2018 / Published online: 17 November 2018

(c) The Author(s) 2018

\begin{abstract}
Biomass-derived adsorbents have been intensively studied due to their competence in reducing pollutants with conventional methods. Flowers are used as source in medicine, cosmetics and even as adsorbents for pollutant abatement. In this study, the microparticles from Chrysanthemum indicum were used as adsorbent for reducing the Congo red dye concentration from synthetic solution. Batch trials were evaluated to understand the influence of factors and optimization was carried out using central composite design. Maximum reduction (84.1\%) achieved under the optimized settings of $\mathrm{pH}(1.0)$, adsorbent dose $(300 \mathrm{ppm})$, stirring speed $(150 \mathrm{rpm})$, and contact time $(75 \mathrm{~min})$ at initial dye concentration $\left(150 \mathrm{ppm}\right.$ at $\left.30^{\circ} \mathrm{C}\right)$. Microparticle size ensured with surface morphology of the adsorbent using electron microscopy and functional groups was studied using infrared spectroscopy techniques, respectively. Regression coefficient $\left(R^{2}\right)$ value was obtained as 0.956 which indicates that the predicted values were in good agreement with their corresponding experimental values for the Congo red dye adsorption. Based on the investigation, it is inferred that the Chrysanthemum indicum flower has the potential for Congo red dye reduction from aqueous solution.
\end{abstract}

Keywords Congo red dye $\cdot$ Chrysanthemum indicum $\cdot$ Adsorption $\cdot$ Central composite design

\section{Introduction}

Several industries extensively use synthetic dyes and generate a large volume of dye effluent. This dye effluent contains enormous salt and organic content and they are less biodegradable. Discharge of these dyes into natural water system without the treatment results in ecological imbalance [1-4]. Synthetic dyes are resistance to the physicochemical reaction and have thermal and optical stability due to the complex aromatic structure [5, 6]. By conventional methods, it is challenging to treat the wastewater which contains dyes $[7,8]$. Azo dyes account for $60-70 \%$ of total dye consumption in many industries [7]. Congo red (CR) is the synthetic anionic azo dye [9] and the effluent had to be adequately treated and discharged into the environment, otherwise it can metabolize into benzidine, which is a human carcinogen

S. Shanthakumar

shanthakumar.s@vit.ac.in

1 Department of Environmental and Water Resources Engineering, School of Civil Engineering, Vellore Institute of Technology (VIT), Vellore 632014, India

2 Eco Tech Labs Private Limited, Chennai 600032, India
[10]. CR dye contains complex aromatic structure which complicates the treatment process. It has thermal and optical stability, and resistance to biodegradation and photodegradation [11]. CR dye is used for staining purpose and as a $\mathrm{pH}$ indicator in the laboratory. It is also used for detecting bacteria, amyloidosis diagnosis and to treat protein folding disorders, dermatological disorders, neurodegenerative diseases, etc. However, CR dye causes allergic reactions and it is a cytotoxic, genotoxic, hematotoxic, neurotoxic, as well as mutagenic substance $[12,13]$. Generally, chemical oxidation, ozonisation, membrane filtration, ion exchange or electrochemical techniques are the different methods used to treat dye-contaminated wastewater. Adsorption is proved to be the best method compared to all other technologies due to its less capital outlay. Detailed literature review shows that various adsorbents were used for Congo red dye removal from wastewater, which includes polypyrrole-polyaniline nanofibers [14], modified zeolites [2], sugarcane bagasse [15], aniline propyl silica xerogel [16], tamarind fruit shell [17], acrylamide-sodium dodecyl sulfate layered double hydroxides [18], mesoporous $\mathrm{ZrO}_{2}$ fibers [19], ammonium aluminum carbonate hydroxide-nickel hydroxide composite [20], zinc oxide-alumina composite [21], nickel cobaltite 
[22] and Funalia trogii [23]. However, some of these are not effective for the anionic dye. The biosorbent (Chrysanthemum indicum) belongs to Asteraceae family and are known as Indian chrysanthemum which are widely used for decoration purposes [24, 25]. Further, the literature review indicates that Chrysanthemum indicum flowers (CIF) which are used in this study as an adsorbent for CR dye removal have not yet been studied previously. In India, CIF is generally used for the ornamental purpose and the regular return of CIF is 16.7 tons/hectare that is reported in our previous study [26]. The main aim deals with CIF ability as an adsorbent to treat synthetic CR dye wastewater. CCD is widely adapted to observe the effect of individual process factors and their interactive effects.

\section{Materials and methods}

\section{Microparticles}

CIF was obtained from the native marketplaces of Vellore district, Tamil Nadu, India and meticulously washed to remove dust and dirt particles. Petals were collected and dried and powdered using a domestic mixer. This powder was sieved. Particles of size less than 100 microns were further used as an adsorbent. Physical characteristics of the microparticles are presented elsewhere [26].

\section{Dye}

Congo red (CR) dye $\left(\mathrm{C}_{32} \mathrm{H}_{22} \mathrm{~N}_{6} \mathrm{Na}_{2} \mathrm{O}_{6} \mathrm{~S}_{2}\right.$; MW- 696.665; $\lambda_{\max }=497 \mathrm{~nm}$ ) working derivative solutions made appropriately by diluting the stock solution $\left(1 \mathrm{mg} \mathrm{mL}^{-1}\right)$ with double distilled water.

\section{Adsorption experiment}

Experimental trials were carried based on the procedure mentioned in our previous studies [26]. 250-mL Erlenmeyer flasks were used with $100 \mathrm{~mL}$ of CR dye solution based on the experimental run generated as mentioned in Table 1. Changes in the reduction were analyzed in the residual supernatant obtained after centrifugation $(8000 \mathrm{rpm}$ for $10 \mathrm{~min})$ by UV-Vis spectrophotometer $(\lambda-497 \mathrm{~nm})$. Percentage dye reduction was calculated using the following equation:
Table 1 Level of independent variables and experimental range

\begin{tabular}{|c|c|c|c|c|}
\hline \multirow[t]{2}{*}{ Independent variables } & \multirow{2}{*}{$\begin{array}{l}\text { Design vari- } \\
\text { ables }\end{array}$} & \multicolumn{3}{|c|}{ Range and levels } \\
\hline & & -1 & 0 & +1 \\
\hline $\mathrm{pH}$ & $\mathrm{F}_{1}$ & 4 & 6 & 8 \\
\hline Adsorbent dose $(\mathrm{g} / \mathrm{L})$ & $\mathrm{F}_{2}$ & 2 & 3 & 4 \\
\hline Initial dye conc. (mg/L) & $\mathrm{F}_{3}$ & 100 & 150 & 200 \\
\hline RPM & $\mathrm{F}_{4}$ & 100 & 150 & 200 \\
\hline Contact time (min) & $\mathrm{F}_{5}$ & 60 & 75 & 90 \\
\hline Temperature $\left({ }^{\circ} \mathrm{C}\right)$ & $\mathrm{F}_{6}$ & 25 & 30 & 35 \\
\hline
\end{tabular}

Percentage reduction $=\left[\left(C_{\mathrm{i}}-C_{\mathrm{f}}\right) / C_{\mathrm{i}}\right] \times 100$,

where $C_{\mathrm{i}}, C_{\mathrm{f}}$ are the initial and final dye concentrations $\left(\mathrm{mg} \mathrm{L}^{-1}\right)$, respectively.

\section{Experimental design}

In tradition method of adsorption, variable response effect is studied by varying one variable at a time, ending up in large experimental trails associated with high time consumption process without representing the interaction effect between factors. Therefore, RSM is considered as one of the most useful methods for optimizing the process and portray the influence by several parameters [27, 28]. The experimental trails are carried out based on the quadratic equation (Eq. 1) between the independent variable and coefficients of central composite design (CCD), as expressed below:

$y=\mu_{0}+\mu_{1} F_{1}+\mu_{2} F_{2}+\cdots+\mu_{n} F_{n} \pm c$,

where $y$ is the response (yield), $\mu$ is the response function, $\mathrm{c}$ is the error, and $F_{1}, F_{2}, F_{3} \ldots F_{\mathrm{n}}$ are the independent process parameters.

\section{Results and discussion}

\section{Central composite design}

Based on CCD principle, the design of six variables consists of 53 experiments that are calculated by the following expression:

$N=2^{M-1}+2 M+f_{0}$,

where $N$ is an experimental trail, $M$ is the independent variables, and $f_{0}$ is the central points.

Table 1 shows the independent variables and their experimental range. Table 2 shows the $2^{6}$ fractional factorial design CCD matrix.

Equation 2 is expanded to $\mathrm{Eq} 3$ for a six-variable design: 
Table 2 Fractional factorial CCD matrix with code and real variables

\begin{tabular}{|c|c|c|c|c|c|c|c|c|c|c|c|c|}
\hline Run & $\mathrm{F}_{1}$ & $\mathrm{~F}_{2}$ & $\mathrm{~F}_{3}$ & $\mathrm{~F}_{4}$ & $\mathrm{~F}_{5}$ & $\mathrm{~F}_{6}$ & $\mathrm{pH}$ & $\begin{array}{l}\text { Ads. } \\
\text { dose } \\
(\mathrm{g} / \mathrm{L})\end{array}$ & $\begin{array}{l}\text { Ini.dye } \\
\text { conc. } \\
\text { (mg/L) }\end{array}$ & RPM & $\begin{array}{l}\text { Contact } \\
\text { time } \\
\text { (min.) }\end{array}$ & Temp. $\left({ }^{\circ} \mathrm{C}\right)$ \\
\hline 1 & 0 & 0 & 0 & 2 & 0 & 0 & 6 & 3.0 & 150 & 270 & 75 & 30 \\
\hline 2 & 1 & 1 & -1 & 1 & 1 & -1 & 8 & 4.0 & 100 & 200 & 90 & 25 \\
\hline 3 & 0 & -2 & 0 & 0 & 0 & 0 & 6 & 0.6 & 150 & 150 & 75 & 30 \\
\hline 4 & 0 & 0 & 0 & 0 & 0 & 0 & 6 & 3.0 & 150 & 150 & 75 & 30 \\
\hline 5 & 1 & 1 & 1 & -1 & 1 & -1 & 8 & 4.0 & 200 & 100 & 90 & 25 \\
\hline 6 & 0 & 0 & 0 & 0 & 0 & -2 & 6 & 3.0 & 150 & 150 & 75 & 18 \\
\hline 7 & -1 & 1 & -1 & -1 & -1 & 1 & 4 & 4.0 & 100 & 100 & 60 & 35 \\
\hline 8 & 1 & -1 & -1 & 1 & 1 & 1 & 8 & 2.0 & 100 & 200 & 90 & 35 \\
\hline 9 & 0 & 0 & 0 & 0 & 0 & 2 & 6 & 3.0 & 150 & 150 & 75 & 42 \\
\hline 10 & 0 & 2 & 0 & 0 & 0 & 0 & 6 & 5.4 & 150 & 150 & 75 & 30 \\
\hline 11 & -1 & -1 & 1 & 1 & 1 & 1 & 4 & 2.0 & 200 & 200 & 90 & 35 \\
\hline 12 & 1 & -1 & 1 & -1 & 1 & 1 & 8 & 2.0 & 200 & 100 & 90 & 35 \\
\hline 13 & 0 & 0 & 0 & 0 & 0 & 0 & 6 & 3.0 & 150 & 150 & 75 & 30 \\
\hline 14 & 0 & 0 & 2 & 0 & 0 & 0 & 6 & 3.0 & 270 & 150 & 75 & 30 \\
\hline 15 & -1 & -1 & -1 & -1 & -1 & -1 & 4 & 2.0 & 100 & 100 & 60 & 25 \\
\hline 16 & 1 & 1 & -1 & -1 & -1 & -1 & 8 & 4.0 & 100 & 100 & 60 & 25 \\
\hline 17 & 1 & 1 & -1 & 1 & -1 & 1 & 8 & 4.0 & 100 & 200 & 60 & 35 \\
\hline 18 & 0 & 0 & 0 & 0 & 0 & 0 & 6 & 3.0 & 150 & 150 & 75 & 30 \\
\hline 19 & 1 & -1 & 1 & -1 & -1 & -1 & 8 & 2.0 & 200 & 100 & 60 & 25 \\
\hline 20 & 1 & -1 & 1 & 1 & -1 & 1 & 8 & 2.0 & 200 & 200 & 60 & 35 \\
\hline 21 & 1 & -1 & -1 & -1 & -1 & 1 & 8 & 2.0 & 100 & 100 & 60 & 35 \\
\hline 22 & -1 & 1 & -1 & 1 & 1 & 1 & 4 & 4.0 & 100 & 200 & 90 & 35 \\
\hline 23 & -1 & -1 & 1 & -1 & -1 & 1 & 4 & 2.0 & 200 & 100 & 60 & 35 \\
\hline 24 & -1 & 1 & 1 & -1 & 1 & 1 & 4 & 4.0 & 200 & 100 & 90 & 35 \\
\hline 25 & 1 & 1 & 1 & 1 & -1 & -1 & 8 & 4.0 & 200 & 200 & 60 & 25 \\
\hline 26 & 0 & 0 & 0 & -2 & 0 & 0 & 6 & 3.0 & 150 & 30 & 75 & 30 \\
\hline 27 & 0 & 0 & 0 & 0 & 0 & 0 & 6 & 3.0 & 150 & 150 & 75 & 30 \\
\hline 28 & 1 & 1 & -1 & -1 & 1 & 1 & 8 & 4.0 & 100 & 100 & 90 & 35 \\
\hline 29 & -1 & -1 & -1 & 1 & -1 & 1 & 4 & 2.0 & 100 & 200 & 60 & 35 \\
\hline 30 & -1 & 1 & 1 & 1 & -1 & 1 & 4 & 4.0 & 200 & 200 & 60 & 35 \\
\hline 31 & 1 & 1 & 1 & 1 & 1 & 1 & 8 & 4.0 & 200 & 200 & 90 & 35 \\
\hline 32 & 1 & -1 & -1 & -1 & 1 & -1 & 8 & 2.0 & 100 & 100 & 90 & 25 \\
\hline 33 & 1 & -1 & -1 & 1 & -1 & -1 & 8 & 2.0 & 100 & 200 & 60 & 25 \\
\hline 34 & 0 & 0 & 0 & 0 & 0 & 0 & 6 & 3.0 & 150 & 150 & 75 & 30 \\
\hline 35 & 0 & 0 & 0 & 0 & 0 & 0 & 6 & 3.0 & 150 & 150 & 75 & 30 \\
\hline 36 & 1 & -1 & 1 & 1 & 1 & -1 & 8 & 2.0 & 200 & 200 & 90 & 25 \\
\hline 37 & 0 & 0 & 0 & 0 & -2 & 0 & 6 & 3.0 & 150 & 150 & 40 & 30 \\
\hline 38 & 0 & 0 & 0 & 0 & 0 & 0 & 6 & 3.0 & 150 & 150 & 75 & 30 \\
\hline 39 & 2 & 0 & 0 & 0 & 0 & 0 & 11 & 3.0 & 150 & 150 & 75 & 30 \\
\hline 40 & 0 & 0 & -2 & 0 & 0 & 0 & 6 & 3.0 & 30 & 150 & 75 & 30 \\
\hline 41 & -1 & 1 & 1 & -1 & -1 & -1 & 4 & 4.0 & 200 & 100 & 60 & 25 \\
\hline 42 & 0 & 0 & 0 & 0 & 2 & 0 & 6 & 3.0 & 150 & 150 & 110 & 30 \\
\hline 43 & 0 & 0 & 0 & 0 & 0 & 0 & 6 & 3.0 & 150 & 150 & 75 & 30 \\
\hline 44 & -1 & -1 & -1 & -1 & 1 & 1 & 4 & 2.0 & 100 & 100 & 90 & 35 \\
\hline 45 & -1 & -1 & 1 & -1 & 1 & -1 & 4 & 2.0 & 200 & 100 & 90 & 25 \\
\hline 46 & -1 & -1 & 1 & 1 & -1 & -1 & 4 & 2.0 & 200 & 200 & 60 & 25 \\
\hline 47 & -1 & 1 & -1 & 1 & -1 & -1 & 4 & 4.0 & 100 & 200 & 60 & 25 \\
\hline 48 & -1 & 1 & 1 & 1 & 1 & -1 & 4 & 4.0 & 200 & 200 & 90 & 25 \\
\hline 49 & -1 & 1 & -1 & -1 & 1 & -1 & 4 & 4.0 & 100 & 100 & 90 & 25 \\
\hline
\end{tabular}


Table 2 (continued)

\begin{tabular}{lrrrrrrrlllll}
\hline Run & $\mathrm{F}_{1}$ & $\mathrm{~F}_{2}$ & $\mathrm{~F}_{3}$ & $\mathrm{~F}_{4}$ & $\mathrm{~F}_{5}$ & $\mathrm{~F}_{6}$ & $\mathrm{pH}$ & $\begin{array}{l}\text { Ads. } \\
\text { dose } \\
(\mathrm{g} / \mathrm{L})\end{array}$ & $\begin{array}{l}\text { Ini.dye } \\
\text { conc. } \\
(\mathrm{mg} / \mathrm{L})\end{array}$ & $\mathrm{RPM}$ & $\begin{array}{l}\text { Contact } \\
\text { time } \\
(\mathrm{min} .)\end{array}$ & Temp. $\left({ }^{\circ} \mathrm{C}\right)$ \\
\hline 50 & -1 & -1 & -1 & 1 & 1 & -1 & 4 & 2.0 & 100 & 200 & 90 & 25 \\
51 & 1 & 1 & 1 & -1 & -1 & 1 & 8 & 4.0 & 200 & 100 & 60 & 35 \\
52 & -2 & 0 & 0 & 0 & 0 & 0 & 1 & 3.0 & 150 & 150 & 75 & 30 \\
53 & 0 & 0 & 0 & 0 & 0 & 0 & 6 & 3.0 & 150 & 150 & 75 & 30 \\
\hline
\end{tabular}

$$
\begin{aligned}
y= & \mu_{0}+\mu_{1} F_{1}+\mu_{2} F_{2}+\mu_{3} F_{3}+\mu_{4} F_{4}+\mu_{5} F_{6} \\
& +\mu_{11} F_{12}+\mu_{22} F_{22}+\mu_{33} F_{32}+\mu_{44} F_{42} \\
& +\mu_{55} F_{52}+\mu_{66} F_{62}+\mu_{12} F_{1} F_{2}+\mu_{13} F_{1} F_{3} \\
& +\mu_{14} F_{1} F_{4}+\mu_{15} F_{1} F_{5}+\mu_{16} F_{1} F_{6}+\mu_{23} F_{2} F_{3} \\
& +\mu_{24} F_{2} F_{4}+\mu_{25} F_{2} F_{5}+\mu_{26} F_{2} F_{6}+\mu_{34} F_{3} F_{4} \\
& +\mu_{35} F_{3} F_{5}+\mu_{36} F_{3} F_{6}+\mu_{45} F_{4} F_{5}+\mu_{46} F_{4} F_{6} \\
& +\mu_{56} F_{5} F_{6},
\end{aligned}
$$

where $y$ is the dye removal (\%); $F_{1}, F_{2}, F_{3}, F_{4}, F_{5}$ are the independent variables; $\mu_{0}$ is the regression coefficient; $\mu_{1}, \mu_{2}$, $\mu_{3}, \mu_{4}, \mu_{5}, \mu_{6}$ are the linear coefficients; $\mu_{11}, \mu_{22}, \mu_{33}, \mu_{44}, \mu_{55}$, $\mu_{66}$ are the quadratic coefficients; and $\mu_{12}, \mu_{13}, \mu_{14}, \mu_{15}, \mu_{16}$, $\mu_{23}, \mu_{24}, \mu_{25}, \mu_{26}, \mu_{34}, \mu_{35}, \mu_{36}, \mu_{45}, \mu_{46}, \mu_{56}$ are the interaction coefficients.

With the coefficients in Eq 3:

$$
\begin{aligned}
y= & 59.3528-3.8176 F_{1}+5.9990 F_{2}-3.1209 F_{3} \\
& +0.7326 F_{4}+2.1713 F_{5}-0.4646 F_{6} \\
& +2.0057 F_{12}-0.4492 F_{22}+0.7676 F_{32} \\
& -0.6081 F_{42}-1.1907 F_{52}+1.3164 F_{62} \\
& -0.0364 F_{1} F_{2}+.9034 F_{1} F_{3}-0.2190 F_{1} F_{4} \\
& +4.3763 F_{1} F_{5}-1.1797 F_{1} F_{6}+1.0092 F_{2} F_{3} \\
& -0.5795 F_{2} F_{4}+3.4821 F_{2} F_{5}+0.3418 F_{2} F_{6} \\
& +2.7554 F_{3} F_{4}-1.0721 F_{3} F_{5}+1.4783 F_{3} F_{6} \\
& +0.4062 F_{4} F_{5}-2.2752 F_{4} F_{6}+0.5504 F_{5} F_{6} .
\end{aligned}
$$

\section{Microparticle characteristics}

The morphology of pre- and post-treated adsorbents surface was studied using scanning electron microscopic technique and presented in Fig. 1. It can be observed from the figure that the surface of the adsorbent was irregular and multifarious in nature. In addition, the particles are asymmetric and the uneven surface increases the physical adsorption. FTIR spectrum depicts the functional groups present in the adsorbent [29]. Figure 2 shows the FTIR spectra ranging between 400 and $4000 \mathrm{~cm}^{-1}$ of adsorbent pre- and post-experimental trails. In Fig. 2, the peaks at wavenumbers 1737.8 and $1600.9 \mathrm{~cm}^{-1}$ indicate the presence of $\mathrm{C}=\mathrm{O}$ group. Broad absorption near $3400-2400 \mathrm{~cm}^{-1}$ confirms the occurrence of O-H group.
Strong intensity absorptions near $1300-1000 \mathrm{~cm}^{-1}$ show the presence of esters(C-O group). Some functional group's peaks in figure are shifted after adsorption. The downshift of the wavenumber from 1600 to $1641 \mathrm{~cm}^{-1}$ indicates the bending vibrations of $\mathrm{N}-\mathrm{H}$ group in the adsorption process. The intensity of peaks at the regions $1737 \mathrm{~cm}^{-1}, 1641 \mathrm{~cm}^{-1}, 1429 \mathrm{~cm}^{-1}$, $1365 \mathrm{~cm}^{-1}, 1228 \mathrm{~cm}^{-1}, 1149 \mathrm{~cm}^{-1}$ significantly shifted due to the adsorbent contact with $\mathrm{CR}$, indicating the complexation and attachment to the surface of the dye
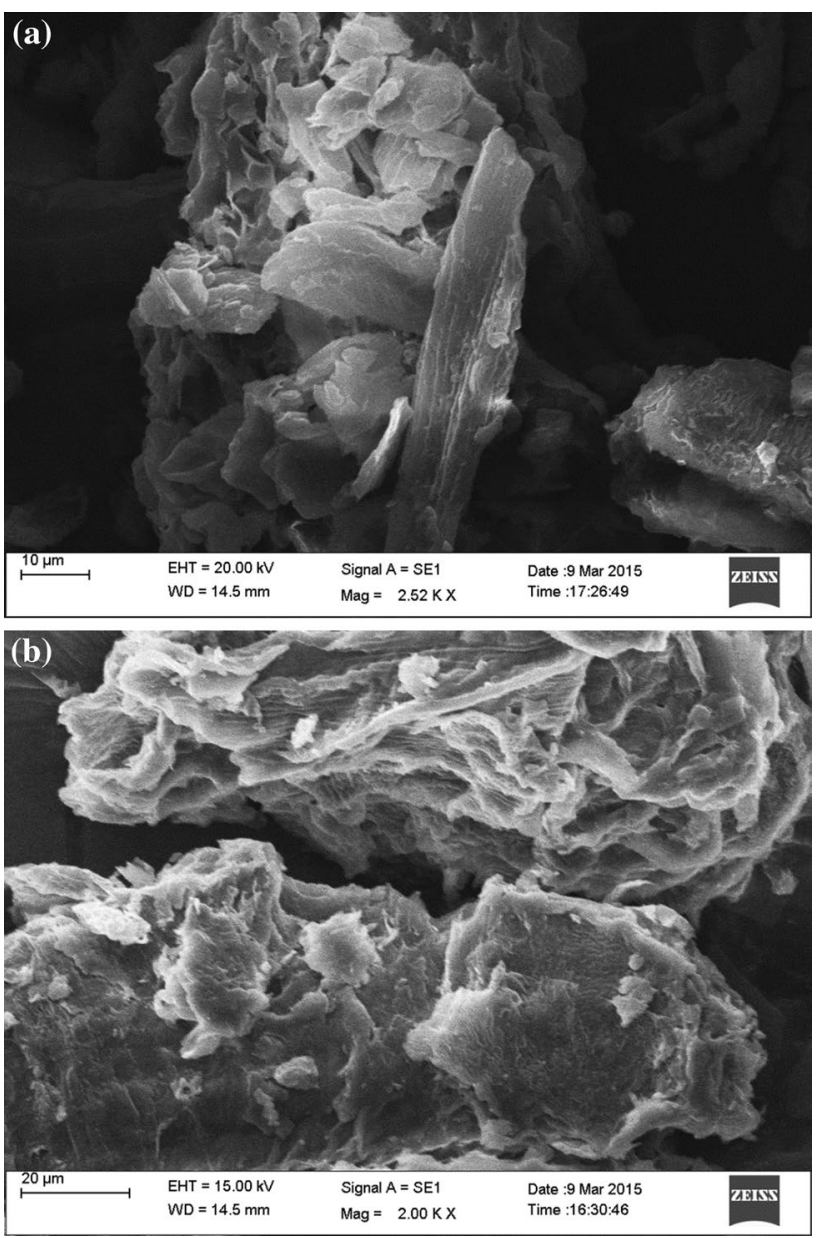

Fig. 1 SEM images of a raw and $\mathbf{b}$ CR dye-loaded adsorbent 
Fig. 2 FTIR spectra of a raw and $\mathbf{b}$ CR dye-loaded adsorbent
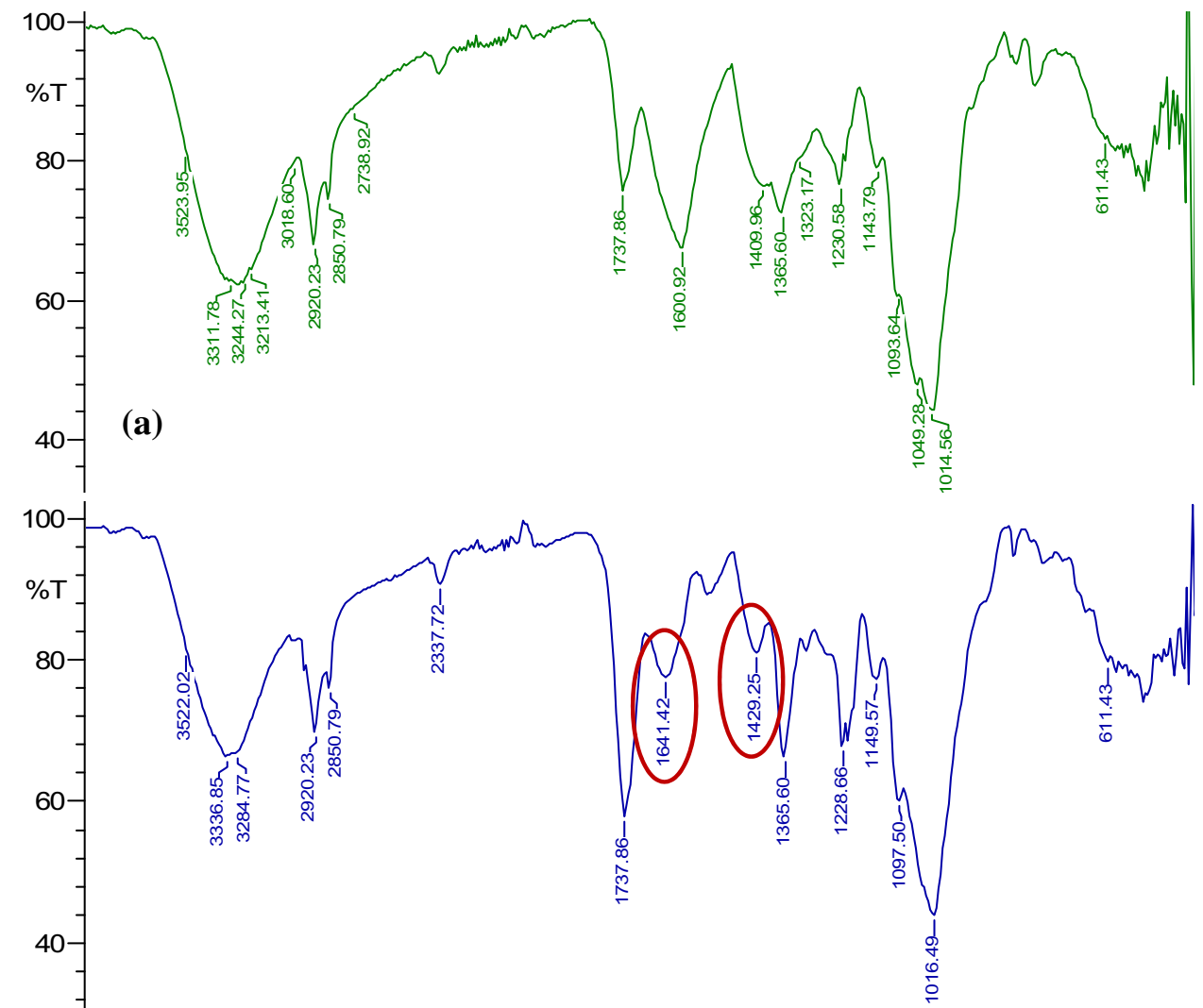

(b)

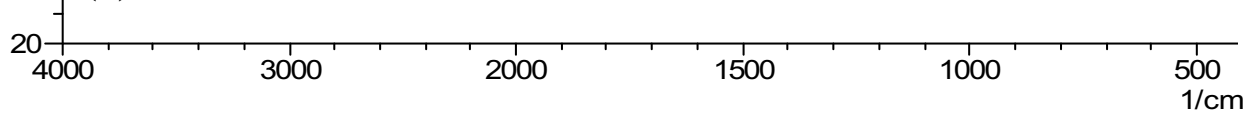

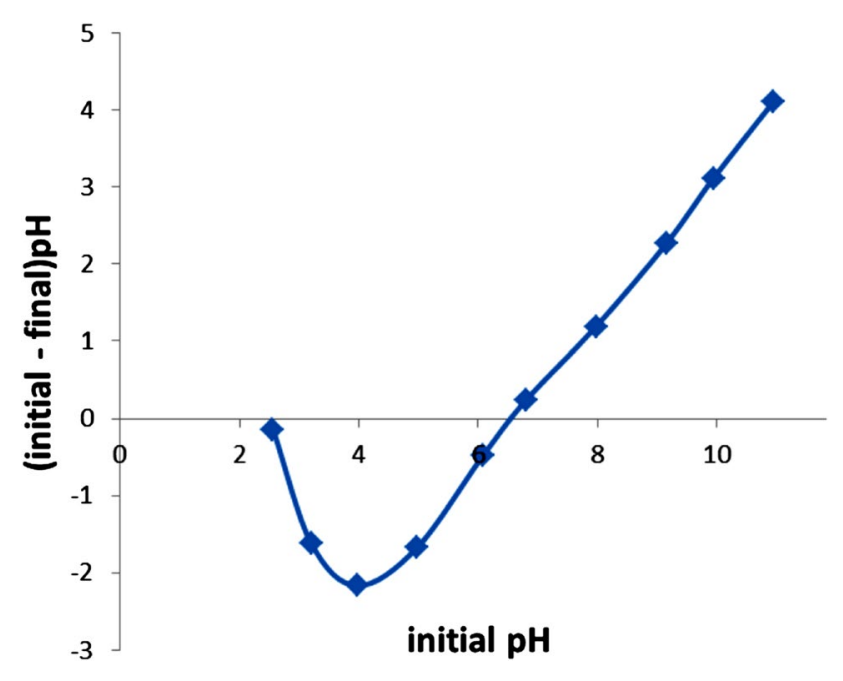

Fig. 3 Point of zero charge

\section{Point of zero charge (PZC)}

PZC is to determine the $\mathrm{pH}$ influence on CR dye removal. $100 \mathrm{~mL}$ of double distilled water has taken in conical flasks. Adjust the $\mathrm{pH}$ of all flasks from 2 to 10 using $0.1 \mathrm{~N}$ $\mathrm{NaOH}$ and $0.1 \mathrm{~N} \mathrm{HCl}$ and take as initial $\mathrm{pH}$. Add $0.1 \mathrm{~g}$ of adsorbent to all flasks and agitated at $120 \mathrm{rpm}$ for $24 \mathrm{~h}$. Measure the $\mathrm{pH}$ after equilibrium which has been considered as final $\mathrm{pH}$. Plot the graph of initial $\mathrm{pH}$ vs difference in initial and final $\mathrm{pH}$ values. The $\mathrm{pH}$ at which it is zero is considered as PZC value. From Fig. 3, it is noted that PZC value of $\mathrm{CI}$ is 6.6. This shows that at $\mathrm{pH}<6.6$, CI adsorbent carries positive surface charge, whereas at $\mathrm{pH}>6.6$ adsorbent carries negative surface charge.

\section{Response surface methodology}

Table 1 shows the independent variables and their experimental range. Table 2 shows the $2^{6}$ fractional factorial design CCD matrix, whereas Table 3 depicts the experimental results and predicted. Analysis of variance (ANOVA) which is used in evaluating adequacy and significance of the model is shown in Table 4. Values from the ANOVA table indicate that all variables and their interactions are significant. Degree of significance of each variable is represented by $p$ value and variation of the data about its mean is described by $F$-value [30]. $R^{2}(0.9569)$ value shows the 
Table 3 Fractional factorial CCD matrix and the output response for dye removal

\begin{tabular}{|c|c|c|c|c|c|c|c|c|}
\hline Run & $\mathrm{pH}$ & $\begin{array}{l}\text { Ads. dose } \\
(\mathrm{g} / \mathrm{L})\end{array}$ & $\begin{array}{l}\text { Ini.dye } \\
\text { conc. } \\
\text { (mg/L) }\end{array}$ & $\mathrm{Rpm}$ & $\begin{array}{l}\text { Contact } \\
\text { time (min.) }\end{array}$ & Temp. $\left({ }^{\circ} \mathrm{C}\right)$ & $\begin{array}{l}\text { Dye removal } \\
\text { (\%) exp. }\end{array}$ & $\begin{array}{l}\text { Dye } \\
\text { removal } \\
\text { (\%) pre. }\end{array}$ \\
\hline 1 & 6 & 3.0 & 150 & 270 & 75 & 30 & 57.453 & 57.655 \\
\hline 2 & 8 & 4.0 & 100 & 200 & 90 & 25 & 78.727 & 76.740 \\
\hline 3 & 6 & 0.6 & 150 & 150 & 75 & 30 & 43.870 & 42.544 \\
\hline 4 & 6 & 3.0 & 150 & 150 & 75 & 30 & 57.453 & 59.353 \\
\hline 5 & 8 & 4.0 & 200 & 100 & 90 & 25 & 66.742 & 65.992 \\
\hline 6 & 6 & 3.0 & 150 & 150 & 75 & 18 & 71.336 & 67.904 \\
\hline 7 & 4 & 4.0 & 100 & 100 & 60 & 35 & 75.581 & 76.806 \\
\hline 8 & 8 & 2.0 & 100 & 200 & 90 & 35 & 52.360 & 51.333 \\
\hline 9 & 6 & 3.0 & 150 & 150 & 75 & 42 & 64.644 & 65.694 \\
\hline 10 & 6 & 5.4 & 150 & 150 & 75 & 30 & 72.135 & 71.080 \\
\hline 11 & 4 & 2.0 & 200 & 200 & 90 & 35 & 52.734 & 51.004 \\
\hline 12 & 8 & 2.0 & 200 & 100 & 90 & 35 & 48.689 & 49.244 \\
\hline 13 & 6 & 3.0 & 150 & 150 & 75 & 30 & 59.750 & 59.353 \\
\hline 14 & 6 & 3.0 & 270 & 150 & 75 & 30 & 53.814 & 56.272 \\
\hline 15 & 4 & 2.0 & 100 & 100 & 60 & 25 & 69.432 & 70.636 \\
\hline 16 & 8 & 4.0 & 100 & 100 & 60 & 25 & 54.157 & 56.730 \\
\hline 17 & 8 & 4.0 & 100 & 200 & 60 & 35 & 39.255 & 43.612 \\
\hline 18 & 6 & 3.0 & 150 & 150 & 75 & 30 & 56.954 & 59.353 \\
\hline 19 & 8 & 2.0 & 200 & 100 & 60 & 25 & 41.798 & 42.535 \\
\hline 20 & 8 & 2.0 & 200 & 200 & 60 & 35 & 49.213 & 47.303 \\
\hline 21 & 8 & 2.0 & 100 & 100 & 60 & 35 & 50.262 & 49.832 \\
\hline 22 & 4 & 4.0 & 100 & 200 & 90 & 35 & 73.184 & 73.288 \\
\hline 23 & 4 & 2.0 & 200 & 100 & 60 & 35 & 56.570 & 59.399 \\
\hline 24 & 4 & 4.0 & 200 & 100 & 90 & 35 & 67.640 & 69.065 \\
\hline 25 & 8 & 4.0 & 200 & 200 & 60 & 25 & 59.251 & 59.107 \\
\hline 26 & 6 & 3.0 & 150 & 30 & 75 & 30 & 56.754 & 54.171 \\
\hline 27 & 6 & 3.0 & 150 & 150 & 75 & 30 & 59.151 & 59.353 \\
\hline 28 & 8 & 4.0 & 100 & 100 & 90 & 35 & 78.876 & 77.109 \\
\hline 29 & 4 & 2.0 & 100 & 200 & 60 & 35 & 62.472 & 64.064 \\
\hline 30 & 4 & 4.0 & 200 & 200 & 60 & 35 & 71.236 & 69.258 \\
\hline 31 & 8 & 4.0 & 200 & 200 & 90 & 35 & 73.997 & 73.635 \\
\hline 32 & 8 & 2.0 & 100 & 100 & 90 & 25 & 56.854 & 59.674 \\
\hline 33 & 8 & 2.0 & 100 & 200 & 60 & 25 & 54.307 & 53.725 \\
\hline 34 & 6 & 3.0 & 150 & 150 & 75 & 30 & 58.452 & 59.353 \\
\hline 35 & 6 & 3.0 & 150 & 150 & 75 & 30 & 60.949 & 59.353 \\
\hline 36 & 8 & 2.0 & 200 & 200 & 90 & 25 & 58.052 & 57.668 \\
\hline 37 & 6 & 3.0 & 150 & 150 & 40 & 30 & 50.762 & 47.453 \\
\hline 38 & 6 & 3.0 & 150 & 150 & 75 & 30 & 62.347 & 59.353 \\
\hline 39 & 11 & 3.0 & 150 & 150 & 75 & 30 & 59.656 & 61.619 \\
\hline 40 & 6 & 3.0 & 30 & 150 & 75 & 30 & 75.958 & 71.118 \\
\hline 41 & 4 & 4.0 & 200 & 100 & 60 & 25 & 57.978 & 59.846 \\
\hline 42 & 6 & 3.0 & 150 & 150 & 110 & 30 & 56.854 & 57.781 \\
\hline 43 & 6 & 3.0 & 150 & 150 & 75 & 30 & 60.050 & 59.353 \\
\hline 44 & 4 & 2.0 & 100 & 100 & 90 & 35 & 61.948 & 62.934 \\
\hline 45 & 4 & 2.0 & 200 & 100 & 90 & 25 & 40.329 & 36.814 \\
\hline 46 & 4 & 2.0 & 200 & 200 & 60 & 25 & 61.948 & 64.557 \\
\hline 47 & 4 & 4.0 & 100 & 200 & 60 & 25 & 72.884 & 73.171 \\
\hline 48 & 4 & 4.0 & 200 & 200 & 90 & 25 & 68.689 & 69.961 \\
\hline 49 & 4 & 4.0 & 100 & 100 & 90 & 25 & 74.232 & 76.985 \\
\hline
\end{tabular}


Table 3 (continued)

\begin{tabular}{lllllllll}
\hline Run & $\mathrm{pH}$ & $\begin{array}{l}\text { Ads. dose } \\
(\mathrm{g} / \mathrm{L})\end{array}$ & $\begin{array}{l}\text { Ini.dye } \\
\text { conc. } \\
(\mathrm{mg} / \mathrm{L})\end{array}$ & $\mathrm{Rpm}$ & $\begin{array}{l}\text { Contact } \\
\text { time }(\mathrm{min} .)\end{array}$ & Temp. $\left({ }^{\circ} \mathrm{C}\right)$ & $\begin{array}{l}\text { Dye removal } \\
(\%) \text { exp. }\end{array}$ & $\begin{array}{l}\text { Dye } \\
\text { removal } \\
(\%) \text { pre. }\end{array}$ \\
\hline 50 & 4 & 2.0 & 100 & 200 & 90 & 25 & 59.101 & 62.407 \\
51 & 8 & 4.0 & 200 & 100 & 60 & 35 & 56.255 & 53.791 \\
52 & 1 & 3.0 & 150 & 150 & 75 & 30 & 84.123 & 79.779 \\
53 & 6 & 3.0 & 150 & 150 & 75 & 30 & 58.252 & 59.353 \\
\hline
\end{tabular}

Table 4 ANOVA for fit of dye removal (\%) from central composite design

\begin{tabular}{lrrrrr}
\hline $\begin{array}{l}\text { Sources of } \\
\text { variation }\end{array}$ & $\begin{array}{l}\text { Sum of } \\
\text { squares }\end{array}$ & $D f$ & Mean square & $F$-value & $\mathrm{P}$ \\
\hline Regression & 5110.83 & 27 & 189.29 & 20.58 & 0.000 \\
Linear & 2848.69 & 6 & 474.78 & 51.62 & 0.000 \\
Square & 521.87 & 6 & 86.98 & 9.46 & 0.000 \\
Interaction & 1740.27 & 15 & 116.02 & 12.61 & 0.000 \\
Residuals & 229.94 & 25 & 9.20 & & \\
Total & 5340.77 & & & & \\
$R^{2}=95.69 \% ; R^{2}$ (adjusted) $=91.04 \%$ & & & \\
\hline
\end{tabular}

reliability of the model. 3D surface plots were obtained from the validated model. The obtained $\mathrm{F}$ value $\left(12.72>F_{\text {critical }}\right.$ 1.94 ) is $95 \%$ significant endorses the model is suitable [31]. $R^{2}(0.9569)$ which is near to 1 designates the fit of regression line with the data. From Table 5, the coefficients $\mu_{1}, \mu_{2}, \mu_{3}$ are significant single effects, $\mu_{11}, \mu_{55}, \mu_{66}$ are the significant square effects and $\mu_{13}, \mu_{15}, \mu_{16}, \mu_{25}, \mu_{34}, \mu_{36}, \mu_{46}$ are the significant interactive effects as $p<0.05$.

\section{Interpretation of 3D surface plots}

\section{Effect of $\mathrm{pH}$}

Adsorbent dose As $\mathrm{pH}$ increases dye adsorption decreases this is because at higher $\mathrm{pH}$ level, $\mathrm{OH}^{-}$ions compete with dye anions for active adsorption sites (Fig. 4a). Removal efficiency rises with increase in adsorbent dose due to unsaturated adsorption sites availability. The maximum dye removal is at low $\mathrm{pH}$ and increasing adsorbent dose which arguably would increase the positive terminal site at low $\mathrm{pH}$ to favor adsorption.

Initial dye concentration Maximum percentage dye removal is obtained at low $\mathrm{pH}$ and low dye concentration (Fig. 4b) as dye ions are less than a number of adsorption sites, indicating overlapping of sites (based on PZC value).

$R P M$ Percentage removal of $\mathrm{CR}$ dye decreases as $\mathrm{pH}$ increases with given RPM (Fig. 4c). This is based on the competition of $\mathrm{OH}^{-}$ions with negatively charged dye ions. RPM alone does not have much effect on dye removal.
Table 5 Estimated regression coefficients for removal of dye (\%)

\begin{tabular}{|c|c|c|c|c|}
\hline Term & Coefficient & SE & $T$ & $P$ \\
\hline$\mu_{0}$ & 59.3528 & 1.0093 & 58.808 & 0.000 \\
\hline$\mu_{1}$ & -3.8176 & 0.4608 & -8.284 & 0.000 \\
\hline$\mu_{2}$ & 5.9990 & 0.4608 & 13.018 & 0.000 \\
\hline$\mu_{3}$ & -3.1209 & 0.4608 & -6.773 & 0.000 \\
\hline$\mu_{4}$ & 0.7326 & 0.4608 & 1.590 & 0.124 \\
\hline$\mu_{5}$ & 2.1713 & 0.4608 & 4.712 & 0.000 \\
\hline$\mu_{6}$ & -0.4646 & 0.4608 & -1.008 & 0.323 \\
\hline$\mu_{11}$ & 2.0057 & 0.3936 & 5.096 & 0.000 \\
\hline$\mu_{22}$ & -0.4492 & 0.3936 & -1.141 & 0.265 \\
\hline$\mu_{33}$ & 0.7676 & 0.3936 & 1.950 & 0.062 \\
\hline$\mu_{44}$ & -0.6081 & 0.3936 & -1.545 & 0.135 \\
\hline$\mu_{55}$ & -1.1907 & 0.3936 & -3.025 & 0.006 \\
\hline$\mu_{66}$ & 1.3164 & 0.3936 & 3.345 & 0.003 \\
\hline$\mu_{12}$ & -0.0364 & 0.5361 & -0.068 & 0.946 \\
\hline$\mu_{13}$ & 1.9034 & 0.5361 & 3.550 & 0.002 \\
\hline$\mu_{14}$ & -0.2190 & 0.5361 & -0.409 & 0.686 \\
\hline$\mu_{15}$ & 4.3763 & 0.5361 & 8.163 & 0.000 \\
\hline$\mu_{16}$ & -1.1797 & 0.5361 & -2.201 & 0.037 \\
\hline$\mu_{23}$ & 1.0092 & 0.5361 & 1.882 & 0.071 \\
\hline$\mu_{24}$ & -0.5795 & 0.5361 & -1.081 & 0.290 \\
\hline$\mu_{25}$ & 3.4821 & 0.5361 & 6.495 & 0.000 \\
\hline$\mu_{26}$ & 0.3418 & 0.5361 & 0.638 & 0.530 \\
\hline$\mu_{34}$ & 2.7554 & 0.5361 & 5.140 & 0.000 \\
\hline$\mu_{35}$ & -1.0721 & 0.5361 & -2.000 & 0.057 \\
\hline$\mu_{36}$ & 1.4783 & 0.5361 & 2.757 & 0.011 \\
\hline$\mu_{45}$ & 0.4062 & 0.5361 & 0.758 & 0.456 \\
\hline$\mu_{46}$ & -2.2752 & 0.5361 & -4.244 & 0.000 \\
\hline$\mu_{56}$ & 0.5504 & 0.5361 & 1.027 & 0.314 \\
\hline
\end{tabular}

Maximum removal efficiency is obtained at low $\mathrm{pH}$ and high RPM.

Contact time As $\mathrm{pH}$ increases dye removal decreases (Fig. 4d) by electrostatic repulsion of dye ions and negatively charged adsorbent according to PZC value of the adsorbent. At high $\mathrm{pH}$ as contact time increases removal efficiency of dye molecules increases as sufficient time is available to reach equilibrium.

Temperature At high temperature because of swelling of adsorbent, large dye molecules will penetrate into the adsorbent which intend increases the dye adsorption (Fig. 4e). 


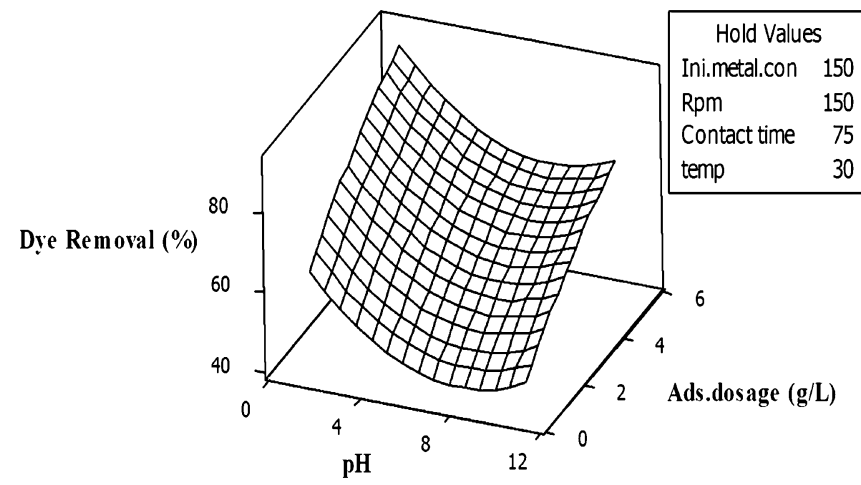

(a)

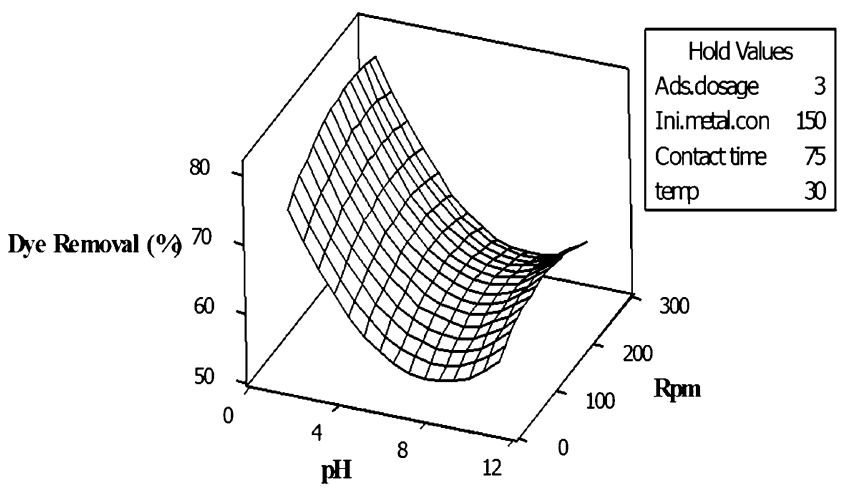

(c)

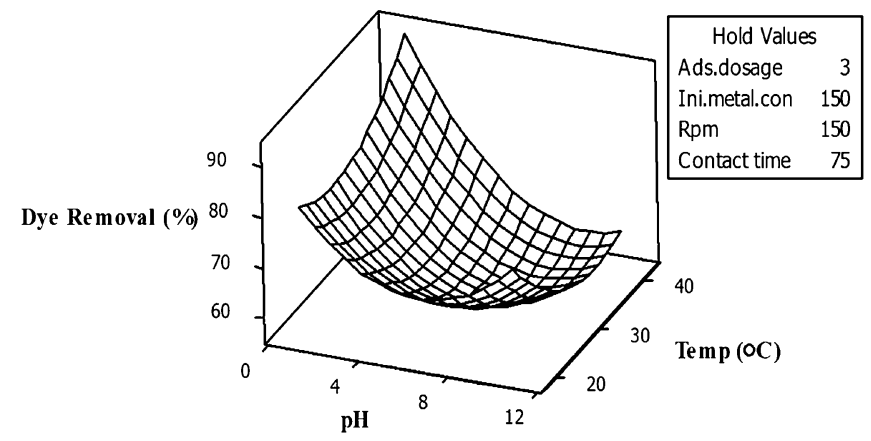

(e)

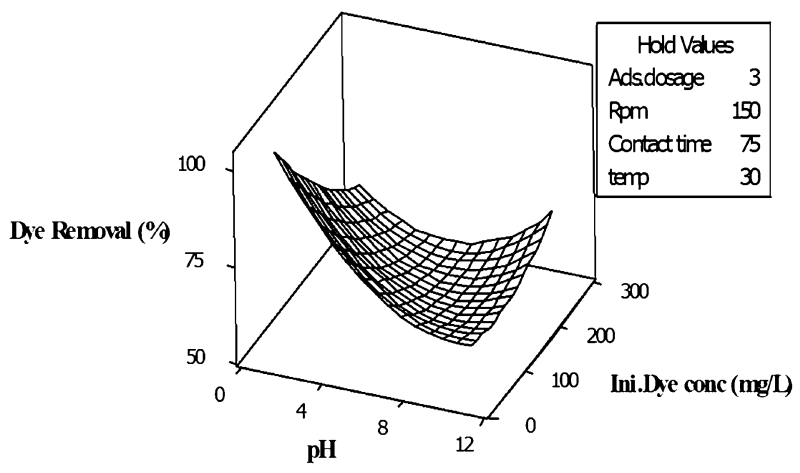

(b)

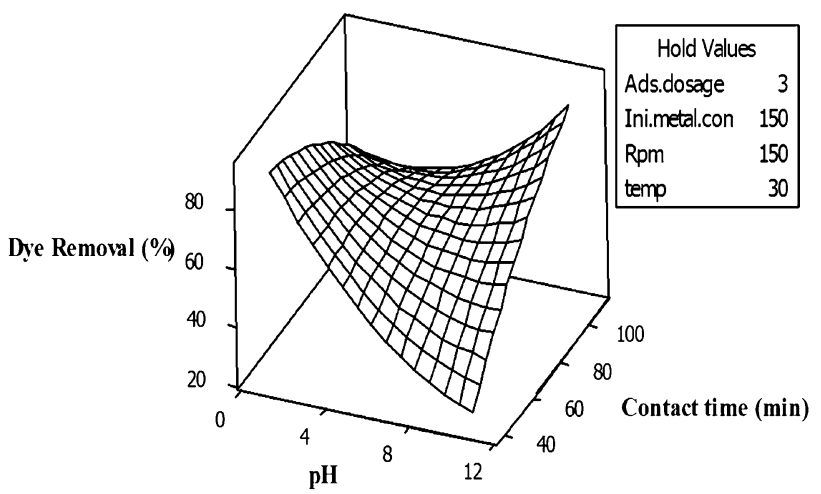

(d)

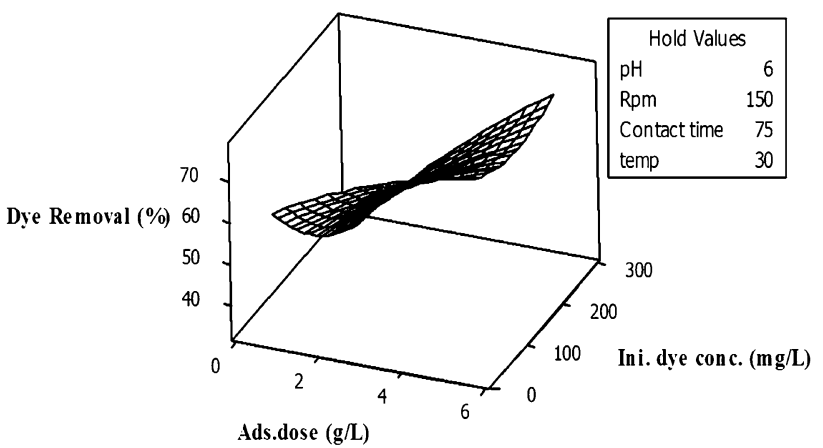

(f)

Fig. 4 Interactive effect of $\mathbf{a} \mathrm{pH}$ and adsorbent dose, $\mathbf{b} \mathrm{pH}$ and initial dye concentration, $\mathbf{c} \mathrm{pH}$ and $\mathrm{RPM}, \mathbf{d} \mathrm{pH}$ and contact time, $\mathbf{e} \mathrm{pH}$ and temperature and $\mathbf{f}$ adsorbent dose and initial dye concentration, on removal of CR dye

Same observation is reported in the literature [32]. Maximum dye removal is seen at low $\mathrm{pH}$ and high temperature. At high $\mathrm{pH}$ region with low-temperature condition removal efficiency increases as mobility of dye molecules decreases which facilitates the adsorption.

\section{Effect of adsorbent dose}

Initial dye concentration The vital factor which limits the sorbent-sorbate equilibrium in the system is adsorbent [33].
Figure $4 \mathrm{f}$ depicts an increase in the removal of dyes with an increase in adsorbent dose and is maximum at a high dosage. This is attributed as the convenience of sufficient amount of unsaturated adsorbent spots for dye molecules.

RPM From Fig. 5a, it can be noted that RPM alone does not have much effect on percentage dye removal. Maximum adsorption of dye molecules is obtained at high adsorbent dose with given RPM. Since adsorbent dose increases the availability of active adsorption sites also increases which intend increases the adsorption. 


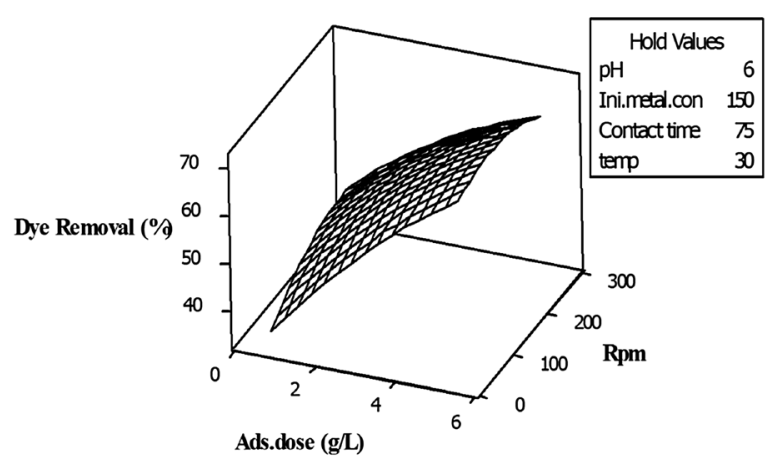

(a)

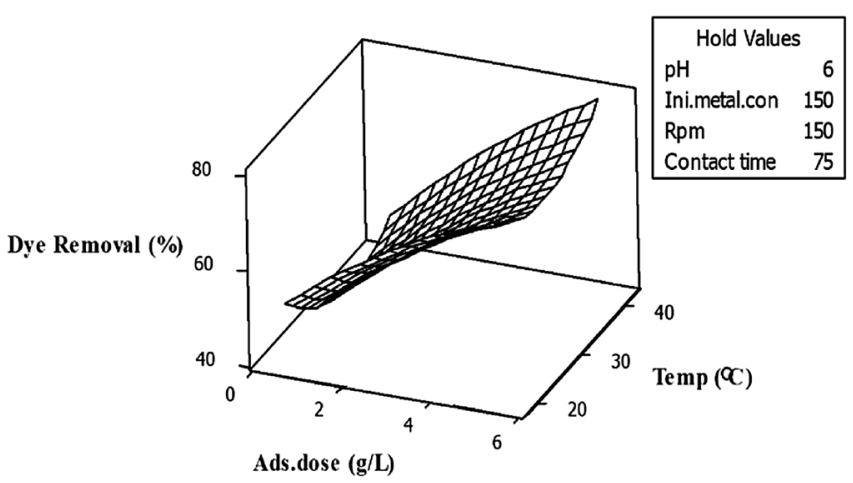

(c)

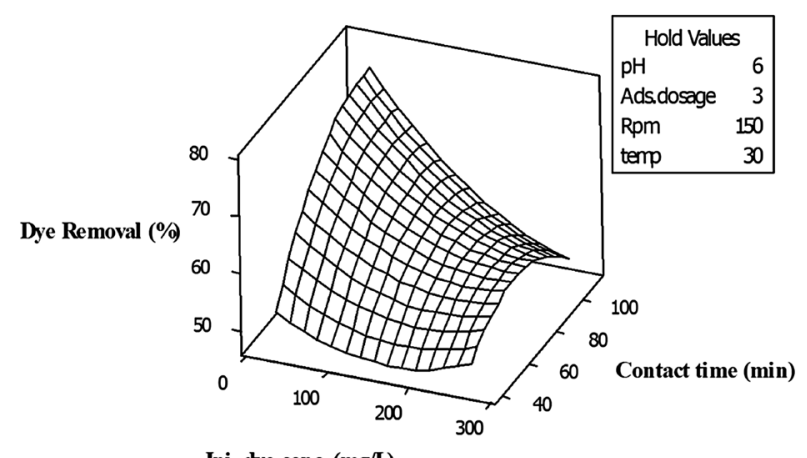

Ini. dye conc. (mg/L)

(e)

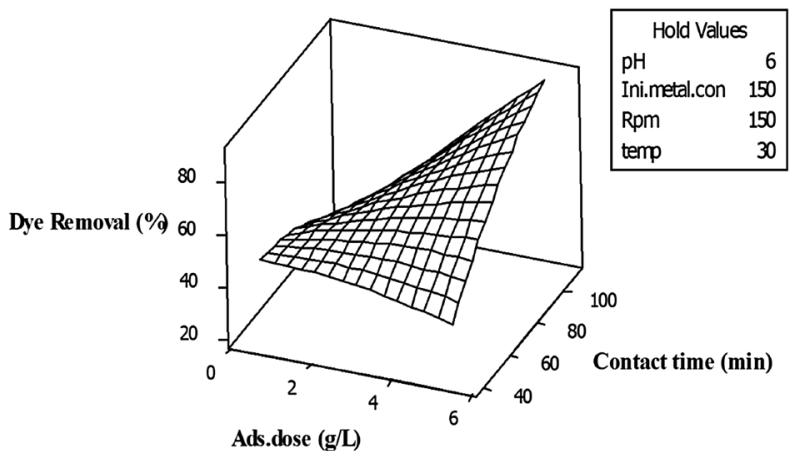

(b)

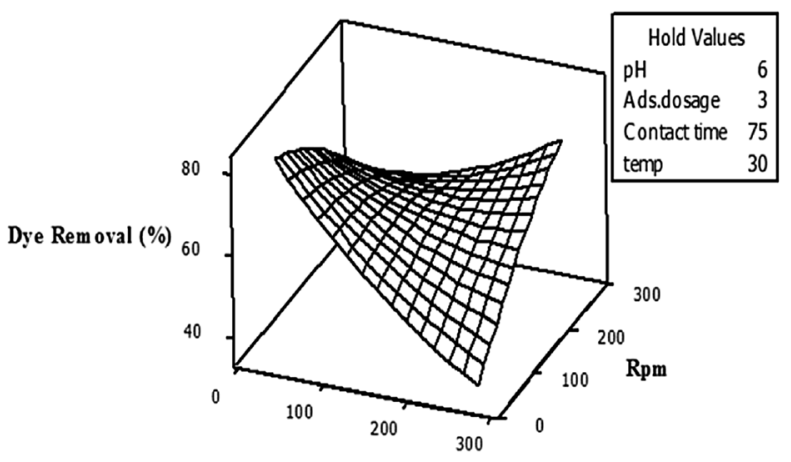

Ini.dye conc. (mg/L)

(d)

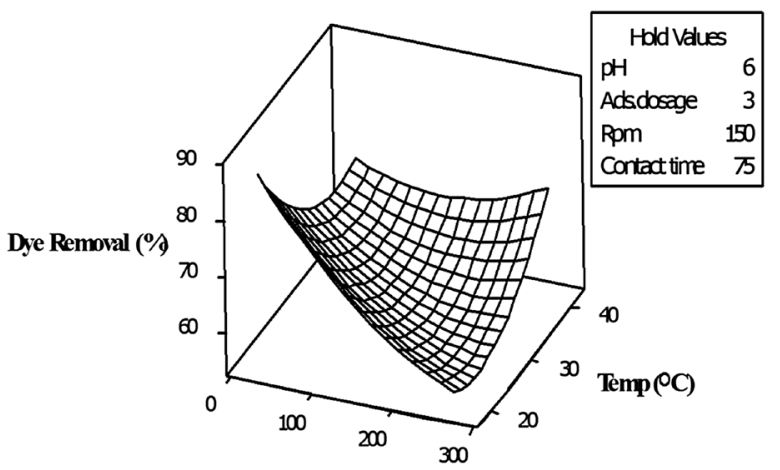

Ini. dye conc. (mg/L)

(f)

Fig. 5 Interactive effect of a adsorbent dose and RPM, b adsorbent dose and contact time, $\mathbf{c}$ adsorbent dose and temperature, $\mathbf{d}$ RPM and initial dye concentration, $\mathbf{e}$ initial dye concentration and contact time and $\mathbf{f}$ initial dye concentration and temperature, on removal of CR dye

Contact time Figure 5b shows at a low dose when contact time increases removal efficiency decreases due to the occurrence of desorption. At high dose, with an increase in contact time adsorption also increases and is maximum at a high dose and high contact time. This is because at high dose, a maximum number of unsaturated adsorption sites are available and sufficient time is available to reach equilibrium.

Temperature Figure 5c shows that as adsorbent dose increases dye adsorption also increases due to an upsurge in adsorption sites. Dye removal decreases first as temperature increases then increase again. This is because at high-temperature viscosity in the medium decreases which increases the diffusion frequency of the dye molecules into adsorbent pores [34]. Moreover, at low temperature, the mobility of the dye molecules decreases which increases the adsorption process. 


\section{Interactions}

RPM and initial dye concentration Removal efficiency declines with an increase in the concentration of dye at lesser RPM (Fig. 5d). This is because of non-availability of enough adsorption sites to attain equilibrium. At high RPM with an increase in dye concentration, percentage dye removal also increases. This is attributed to increased concentration gradient (driving force to overcome mass transfer).

Initial dye concentration and contact time Maximum dye removal efficiency is obtained at low concentration and high

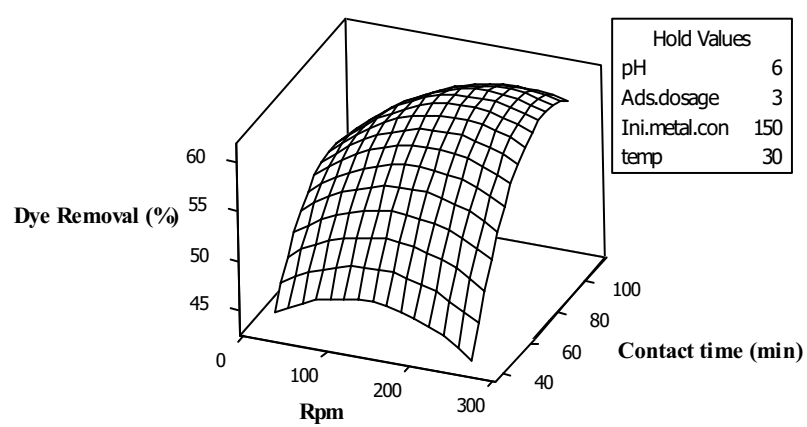

(a)

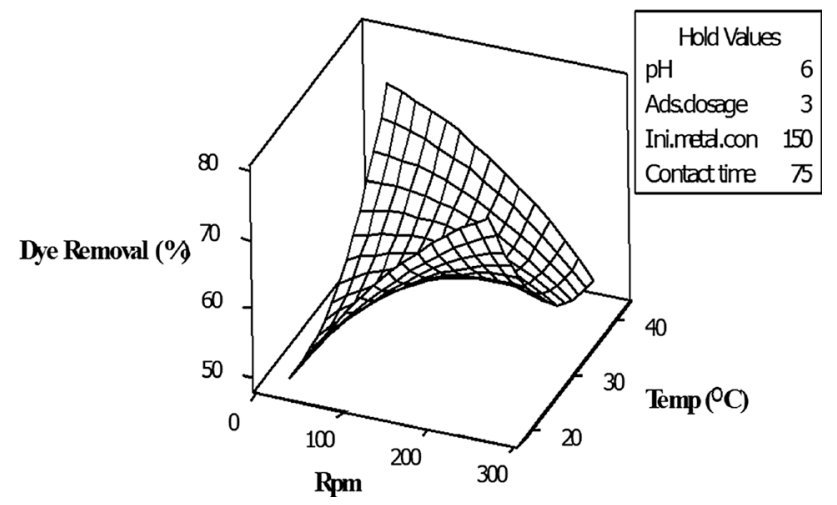

(b)

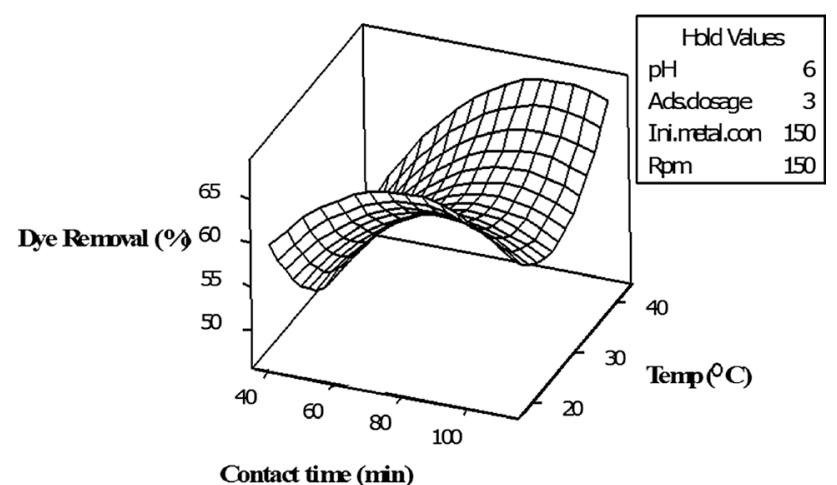

(c)

Fig. 6 Interactive effect of a RPM and contact time, b RPM and temperature, and $\mathbf{c}$ temperature and contact time, on removal of $\mathrm{CR}$ dye contact time (Fig. 5e). This is due to the availability of huge amount of surface capacity for adsorption of dye and enough time for interaction of adsorbent and adsorbate. Removal efficiency decreased at higher adsorbate concentration.

Initial dye concentration and temperature Interactive effect of initial concentration of adsorbate (dye) and the temperature is shown in Fig. 5f. At low temperature, increasing dye concentration decreases the removal rate due to deficiency of adsorption surfaces. As temperature increases surface area of adsorbent increases due to swelling effect which intends increases the adsorption of dye molecules.

RPM and contact time Percentage dye removal increased first with an increase in RPM and then decreases (Fig. 6a). This is because, as RPM increase desorption takes place first and then once again dye molecules adsorbs on the adsorbent. As time increases removal efficiency also increases irrespective of RPM.

RPM and temperature From Fig. $6 \mathrm{~b}$ it can be noted that the maximum removal is seen at less RPM and high temperature due to increase in pore size of the adsorbent. At high temperature, removal efficiency decreases w.r.t RPM. However, at a lesser temperature, percentage removal increases as RPM increases.

Temperature and contact time At higher temperature, when time improves adsorption of dye molecules also increases and is maximum at high time and temperature. This is because of increase in pore size of adsorbent due swelling effect and availability of sufficient time to reach equilibrium. At low temperature, increasing or decreasing of contact time from mid value has obvious decrease in adsorption of dye molecules (Fig. 6c).

Table 6 presents the comparison of CR dye removal in the present study with the different adsorbents. It can be observed from Table 6 that, the CR dye removal from

Table 6 Comparison of CR dye removal from aqueous solution by various adsorbents

\begin{tabular}{lll}
\hline Adsorbents & $\begin{array}{l}\text { Maximum dye } \\
\text { removal (\%) }\end{array}$ & References \\
\hline Australian kaolin & 85 & {$[8]$} \\
NiO/graphene nanosheets & 99.5 & {$[9]$} \\
Bottom ash & 96.9 & {$[12]$} \\
De-oiled soya & 97.1 & {$[12]$} \\
Eichhornia crassipes & 96 & {$[34]$} \\
Phragmites australis & 98 & {$[35]$} \\
Brewers' spent grain & 90 & {$[36]$} \\
Sawdust activated carbon & 96.7 & {$[37]$} \\
Natural clay & 94 & {$[38]$} \\
Burnt clay & 98 & {$[39]$} \\
Biogas waste slurry & 95 & {$[40]$} \\
Chrysanthemum indicum & 84.1 & Present study \\
\hline
\end{tabular}


aqueous solution by Chrysanthemum indicum microparticles is noteworthy and equivalent with other adsorbents reported in the literature.

\section{Conclusion}

Chrysanthemum indicum microparticles showed good ability as an adsorbent to reduce the pollutant CR. This study aims to optimize the process parameters of Congo red dye adsorption from chrysanthemum indicum using a CCD which is a RSM module. The optimum condition for maximum dye removal $(84.1 \%)$ was obtained at $\mathrm{pH} 1$, adsorbent dose $0.3 \mathrm{~g} / 100 \mathrm{ml}$, dye concentration $150 \mathrm{ppm}$, RPM 150, contact time $75 \mathrm{~min}$ and temperature $30^{\circ} \mathrm{C}$. FTIR analysis indicated the formation of new peaks, suggesting the complexation of dye on the surface of the adsorbent. Higher dosage of adsorbent-exhibited better removal of CR from the aqueous solution, suggesting that synthesized microparticles can be used as an efficient adsorbent.

Open Access This article is distributed under the terms of the Creative Commons Attribution 4.0 International License (http://creativecommons.org/licenses/by/4.0/), which permits unrestricted use, distribution, and reproduction in any medium, provided you give appropriate credit to the original author(s) and the source, provide a link to the Creative Commons license, and indicate if changes were made.

\section{References}

1. Kaur S, Rani S, Kumar V, Mahajan RK, Asif M, Tyagi I, Gupta VK (2015) Synthesis, characterization and adsorptive application of ferrocene based mesoporous material for hazardous dye Congo red. J Ind Eng Chem 26:234-242

2. Liu S, Ding Y, Li P, Diao K, Tan X, Lei F, Zhan Y, Li Q, Huang B, Huang Z (2014) Adsorption of the anionic dye Congo red from aqueous solution onto natural zeolites modified with $\mathrm{N}, \mathrm{N}$ dimethyl dehydroabietylamine oxide. Chem Eng J 248:135-144

3. Somasekharareddy MC, Sivaramakrishna L, Varadareddy A (2012) The use of an agricultural waste material, Jujuba seeds for the removal of anionic dye (Congo red) from aqueous medium. J Hazard Mater 203-204:118-127

4. Bayramoglu G, Akbulut A, Liman G, Arica MY (2017) Removal of metal complexed azo dyes from aqueous solution using tris(2-aminoethyl)amine ligand modified magnetic $\mathrm{p}$ (GMAEGDMA) cationic resin: adsorption, isotherm and kinetic studies. Chem Eng Res Des 124:85-97

5. Arica TA, Ayas E, Arica MY (2017) Magnetic MCM-41 silica particles grafted with poly(glycidylmethacrylate) brush: modification and application for removal of direct dyes. Microporous Mesoporous Mater 243:164-175

6. Bayramoglu G, Altintas B, Arica MY (2012) Synthesis and characterization of magnetic beads containing aminated fibrous surfaces for removal of Reactive Green 19 dye: kinetics and thermodynamic parameters. J Chem Technol Biotechnol $87: 705-713$

7. Cheng Z, Zhang L, Guo X, Jiang X, Li T (2015) Adsorption behavior of direct red 80 and congo red onto activated carbon/ surfactant: process optimization, kinetics and equilibrium. Spectrochim Acta Part A Mol Biomol Spectrosc 137:1126-1143

8. Vimonses V, Lei S, Jin B, Chow CWK, Saint C (2009) Adsorption of congo red by three Australian kaolins. Appl Clay Sci 43:465-472

9. Rong X, Qiu F, Qin J, Zhao H, Yan J, Yang D (2015) A facile hydrothermal synthesis, adsorption kinetics and isotherms to Congo Red azo-dye from aqueous solution of NiO/graphene nanosheets adsorbent. J Ind Eng Chem 26:354-363

10. Chatterjee S, Chatterjee S, Chatterjee BP, Guha AK (2007) Adsorptive removal of congo red, a carcinogenic textile dye by chitosan hydrobeads: binding mechanism, equilibrium and kinetics. Colloids Surf A Physicochem Eng Asp 299:146-152

11. Zvezdelina Yaneva VN (2012) Insights into Congo red adsorption on agro-industrial materials—spectral, equilibrium, kinetic, thermodynamic, dynamic and desorption studies. A review. Int Rev Chem Eng 4:127

12. Mittal A, Mittal J, Malviya A, Gupta VK (2009) Adsorptive removal of hazardous anionic dye "Congo red" from wastewater using waste materials and recovery by desorption. J Colloid Interface Sci 340:16-26

13. Shu J, Wang Z, Huang Y, Huang N, Ren C, Zhang W (2015) Adsorption removal of Congo red from aqueous solution by polyhedral $\mathrm{Cu}_{2} \mathrm{O}$ nanoparticles: kinetics, isotherms, thermodynamics and mechanism analysis. J Alloys Compd 633:338-346

14. Bhaumik M, McCrindle R, Maity A (2013) Efficient removal of Congo red from aqueous solutions by adsorption onto interconnected polypyrrole-polyaniline nanofibres. Chem Eng J 228:506-515

15. Zhang Z, Moghaddam L, O'Hara IM, Doherty WOS (2011) Congo Red adsorption by ball-milled sugarcane bagasse. Chem Eng J 178:122-128

16. Pavan FA, Dias SLP, Lima EC, Benvenutti EV (2008) Removal of Congo red from aqueous solution by anilinepropylsilica xerogel. Dye Pigment 76:64-69

17. Somasekharareddy MC (2006) Removal of direct dye from aqueous solutions with an adsorbent made from tamarind fruit shell, an agricultural solid waste. J Sci Ind Res (India) 65:443-446

18. Deng L, Zeng H, Shi Z, Zhang W, Luo J (2018) Sodium dodecyl sulfate intercalated and acrylamide anchored layered double hydroxides: a multifunctional adsorbent for highly efficient removal of Congo red. J Colloid Interface Sci 521:172-182

19. Yu Z, Liu B, Zhou H, Feng C, Wang X, Yuan K, Gan X, Zhu L, Zhang G, Xu D (2017) Mesoporous $\mathrm{ZrO}_{2}$ fibers with enhanced surface area and the application as recyclable absorbent. Appl Surf Sci 399:288-297

20. Zheng Y, Wang H, Cheng B, You W, Yu J (2018) Fabrication of hierarchical bristle-grass-like $\mathrm{NH}_{4} \mathrm{Al}(\mathrm{OH})_{2} \mathrm{CO}_{3} @ \mathrm{Ni}(\mathrm{OH})_{2}$ core-shell structure and its enhanced Congo red adsorption performance. J Alloys Compd 750:644-654

21. Lei C, Pi M, Xu D, Jiang C, Cheng B (2017) Fabrication of hierarchical porous $\mathrm{ZnO}-\mathrm{Al}_{2} \mathrm{O}_{3}$ microspheres with enhanced adsorption performance. Appl Surf Sci 426:360-368

22. Chen H, Zheng Y, Cheng B, Yu J, Jiang C (2018) Chestnut husklike cobaltite hollow microshperes for the adsorption of Congo red. J Alloys Compd 735:1041-1051

23. Bayramoglu G, Arica MY (2018) Adsorption of Congo Red dye by native amine and carboxyl modified biomass of Funalia trogii: isotherms, kinetics and thermodynamics mechanisms. Korean $\mathbf{J}$ Chem Eng 35(6):1303-1311

24. Liu PL, Wan Q, Guo YP, Yang J, Rao GY (2012) Phylogeny of the genus Chrysanthemum L.: evidence from single-copy nuclear gene and chloroplast DNA sequences. PLoS One. https://doi. org/10.1371/journal.pone.0048970 
25. Vilvanathan S, Shanthakumar S (2016) Ni (II) adsorption onto Chrysanthemum indicum: influencing factors, isotherms, kinetics, and thermodynamics. Int J Phytoremediation 18:1046-1059

26. Chukki J, Shanthakumar S (2016) Optimization of malachite green dye removal by Chrysanthemum indicum using response surface methodology. Environ Prog Sustain Energy 35:1415-1419

27. Saeed MO, Azizli K, Isa MH, Bashir MJK (2015) Application of CCD in RSM to obtain optimize treatment of POME using Fenton oxidation process. J Water Process Eng 8:e7-e16

28. Chaudhary N, Balomajumder C (2014) Optimization study of adsorption parameters for removal of phenol on aluminum impregnated fly ash using response surface methodology. J Taiwan Inst Chem Eng 45:852-859

29. Ghorai S, Sarkar AK, Panda AB, Pal S (2013) Effective removal of Congo red dye from aqueous solution using modified xanthan gum/silica hybrid nanocomposite as adsorbent. Bioresour Technol 144:485-491

30. Roy P, Mondal NK, Das K (2014) Modeling of the adsorptive removal of arsenic: a statistical approach. J Environ Chem Eng 2:585-597

31. Hassani A, Soltani RDC, Karaca S, Khataee A (2015) Preparation of montmorillonite-alginate nanobiocomposite for adsorption of a textile dye in aqueous phase: isotherm, kinetic and experimental design approaches. J Ind Eng Chem 21:1197-1207

32. Khodam F, Rezvani Z, Amani-Ghadim AR (2015) Enhanced adsorption of Acid Red 14 by co-assembled LDH/MWCNTs nanohybrid: optimization, kinetic and isotherm. J Ind Eng Chem 21:1286-1294

33. Gohari M, Hosseini SN, Sharifnia S, Khatami M (2013) Enhancement of metal ion adsorption capacity of Saccharomyces cerevisiae's cells by using disruption method. J Taiwan Inst Chem Eng 44:637-645
34. Wanyonyi WC, Onyari JM, Shiundu PM (2014) Adsorption of Congo Red dye from aqueous solutions using roots of Eichhornia crassipes: kinetic and equilibrium studies. Energy Procedia 50:862-869

35. Omran AR, Baiee MA, Juda SA, Salman JM, Alkaim AF (2016) Removal of Congo red dye from aqueous solution using a new adsorbent surface developed from aquatic plant (Phragmites australis). Int J ChemTech Res 9:334-342

36. Kezerle A, Velic N, Hasenay D, Kovacevic D (2018) Lignocellulosic materials as dye adsorbents: adsorption of Methylene Blue and Congo Red on Brewers' spent grain. Croat Chem Acta 91:53-64

37. Kini MS, Prabhu KB, Gundecha A, Devika U (2017) Statistical analysis of Congo Red dye removal using sawdust activated carbon. Int J Appl Eng Res 12:8788-8804

38. Bentahar S, Dbik A, El-khomri M, El-messaoudi N, Bakiz B, Lacherai A (2016) Study of removal of Congo red by local natural clay. St Cerc St CICBIA 17:295-307

39. Mumin MA, Khan MMR, Akhter KF, Uddin MJ (2007) Potentiality of open burnt clay as an adsorbent for the removal of Congo red from aqueous solution. Int J Environ Sci Technol 4:525-532

40. Namasivayam C, Yamuna RT (1992) Removal of Congo red from aqueous solutions by biogas waste slurry. J Chem Tech Biotechnol $53: 153-157$

Publisher's Note Springer Nature remains neutral with regard to jurisdictional claims in published maps and institutional affiliations. 